\title{
Treatment of Keratoconus with WaveLight Contoura and Corneal Cross-Linking Combined [Letter]
}

\section{Neda Shamie}

Maloney-Shamie Vision Institute, Los Angeles, CA, USA
Correspondence: Neda Shamie

Maloney-Shamie Vision Institute, I092I

Wilshire Blvd \#900, Los Angeles, CA,

90024, USA

Tel + I 30I-882-6365

Email ns@maloneyshamie.com

\section{Dear editor}

I read the article entitled "Treatment of Keratoconus with WaveLight Contoura and Corneal Cross-Linking Combined" with great interest, as the management of visual function and treatment of disease progression are two important goals in the care of patients with progressive keratoconus. ${ }^{1}$

I am, however, concerned that conclusions made based on this retrospective study of patients receiving an investigational treatment not approved by the FDA may be over-reaching. While FDA approval for cross-linking is referenced in the article, the UV irradiation parameters described are not enabled on the approved system. Could the author comment on the US approval status of the UV delivery device used?

The article explicitly states that the formulation used was " $0.1 \%$ riboflavin w/Carboxymethyl Cellulose pH Balance (no dextran)" and that "This is also off-label in the US as the FDA approved riboflavin solution has dextran." While there is a dextran-free riboflavin ophthalmic solution with FDA approval (Photrexa, Glaukos), the studied formulation described differs from that formulation, and is not an approved drug product. Unapproved products do not have the same quality controls as approved products, and there is no mechanism for reporting and tracking of adverse occurrences. Use of unapproved drug products is not "off-label" use, nor is it legal within the practice of medicine in the United States, except within the structure of an investigational trial conducted under an IND with the FDA. Therefore, it is of critical importance, both ethically and clinically, to disclose if the treatments performed were part of a clinical trial that fulfilled these requirements.

If the studied treatment described did not utilize the FDA-approved riboflavin ophthalmic solution and cross-linking device, then the investigational procedure cannot be categorized as off-label. Blurring the lines between "unapproved" and "off-label" has substantial implications. The suggestion that these unapproved technologies can be introduced in US ophthalmic practices today outside the confines of a clinical trial undermines the credibility of legitimate off-label use of approved products. 


\section{Disclosure}

Dr Shamie is a consultant for Glaukos and received no consulting fees for this writeup. The author reports no other conflicts of interest in this communication.

\section{Reference}

1. Motwani M. Treatment of Keratoconus with Wavelight Contoura and Corneal Cross-Linking Combined. Clin Ophthalmol. 2021;15:24552472. doi:10.2147/OPTH.S303559

Dove Medical Press encourages responsible, free and frank academic debate. The content of the Clinical Ophthalmology 'letters to the editor' section does not necessarily represent the views of Dove Medical Press, its officers, agents, employees, related entities or the Clinical Ophthalmology editors. While all reasonable steps have been taken to confirm the content of each letter, Dove Medical Press accepts no liability in respect of the content of any letter, nor is it responsible for the content and accuracy of any letter to the editor

\section{Publish your work in this journal}

Clinical Ophthalmology is an international, peer-reviewed journal covering all subspecialties within ophthalmology. Key topics include: Optometry; Visual science; Pharmacology and drug therapy in eye diseases; Basic Sciences; Primary and Secondary eye care; Patient Safety and Quality of Care Improvements. This journal is indexed on PubMed

Submit your manuscript here: https://www.dovepress.com/clinical-ophthalmology-journal
Central and CAS, and is the official journal of The Society of Clinical Ophthalmology (SCO). The manuscript management system is completely online and includes a very quick and fair peer-review system, which is all easy to use. Visit http://www.dovepress.com/ testimonials.php to read real quotes from published authors. 